\title{
A CRÍTICA AO HOMEM OITOCENTISTA NOS FOLHETINS FANTÁSTICOS DE EÇA DE QUEIRÓS
}

\section{THE CRITICISM TO THE 19TH CENTURY MAN IN THE FANTASTIC FEUILLETONS BY EÇA DE QUEIRÓS}

\author{
Jean Carlos Carniel'
}

Luciene Marie Pavanelo²

\begin{abstract}
Resumo: Objetiva-se, com este estudo, uma análise das narrativas "O milhafre", "O lume" e "Memórias duma forca", de Eça de Queirós, publicadas inicialmente no jornal Gazeta de Portugal em 1867, e, postumamente, compiladas no volume Prosas Bárbaras (1903), a fim de compreender como o autor de Os Maias faz uso do fantástico, para fazer uma crítica social ao Oitocentos. De acordo com os pressupostos de Reis (1951) e de Saraiva (1995), reconhecemos Eça como um escritor que dialoga com o fantástico. Deste modo, partindo das reflexōes de Peixinho (2002) e de Nery (2010), sobre o viés fantástico na obra de Eça de Queirós, e de outros críticos que se debruçam sobre a produçăo inicial do autor nascido em Póvoa de Varzim, trataremos de elucidar como Eça traz o fantástico nesses textos, evidenciando a complexidade dessa produçăo, já que, para ele, nâo se trata apenas de trazer o fantástico, uma vez que ele insere assuntos do teor social, fazendo, dessa forma, uma crítica ao homem oitocentista.
\end{abstract}

Palavras-chave: Fantástico. Insólito. Eça de Queirós. Crítica social.

Abstract: The objective of this study is to analyze the narratives "O milhafre", "O lume" and "Memórias duma forca", by Eça de Queirós, initially published in the newspaper Gazeta de Portugal between 1866 and 1867 and, posthumously, compiled in the book Prosas Bárbaras (1903), in order to understand how the author of Os Maias makes use of the fantastic, to make a social criticism to the Nineteenth century. According to the assumptions of Reis (1951) and Saraiva (1995), we recognize Eça as a writer who dialogues with the fantastic. In this way, starting from the reflections of Peixinho (2002)

1 Mestrando em Letras pela Universidade Estadual Paulista (UNESP). Bolsista da FAPESP, processo no 2016/25008-2, Fundaçăo de Amparo à Pesquisa do Estado de Săo Paulo (FAPESP). E-mail: jc.carniel@hotmail.com

2 Doutora em Estudos Comparados de Literaturas de Língua Portuguesa pela Universidade de Sáo Paulo (USP). Professora da Universidade Estadual Paulista (UNESP). E-mail: luciene.pavanelo@unesp.br 
and Nery (2010), on the fantastic in the work of the writer born in Póvoa de Varzim, and other critics who focus on the initial production, we try to elucidate how Eça brings the fantastic in these texts, evidencing a complexity of his production, since, for him, it is not about bringing the fantastic, he brings social content, thus making a criticism of the nineteenth century's man.

Keywords: Fantastic. Unusual. Eça de Queirós. Social Criticism.

Os folhetins publicados por Eça de Queirós na Gazeta de Portugal receberam críticas depreciativas na época de publicaçăo, como é possível constatar pelo depoimento de Jaime Batalha Reis, camarada de Eça de Queirós, que assina a introduçâo de Prosas Bárbaras. Para Reis, essas narrativas foram notadas como uma "novidade extravagante e burlesca. Geral hilaridade os acolheu desde a própria Redaçâo da Gazeta de Portugal, até aos centros intelectuais reconhecidos do país, e até à parte mais grave, culta e influente do público" (1951, p. 7). Além disso, o comentário irônico de Teixeira de Vasconcelos, fundador da Gazeta de Portugal, no qual ele afirma que "tem muito talento este rapaz; mas é pena que estudasse em Coimbra, que haja nos seus contos, sempre, dois cadáveres amando-se num banco do Rossio [...]" (Apud REIS, 1951, p. 8), aponta que, supostamente, os folhetins de Eça tiveram tal recepçăo negativa devido aos temas abordados nesses textos, cuja maioria dialoga com o fantástico, evidenciando, dessa forma, a marginalidade dos escritos fantásticos naquela época.

Jaime Batalha Reis (1951, p. 24), na introduçâo de Prosas Bárbaras, afirma que Eça de Queirós teria sido, entre 1866 e 1867, o mais genial representante português da literatura fantástica. Dessa forma, procuramos evidenciar a parte da produçáo queirosiana que foge dos escopos do paradigma realista/naturalista, e se adentra ao fantástico, sobretudo os primeiros escritos publicados por ele em forma de folhetins. Propomos, portanto, uma visâo alternativa do autor de $O$ primo Basílio, destacando o diálogo com o fantástico.

António José Saraiva é outro crítico que reconhece que há uma visăo cristalizada de Eça como um escritor realista e discorda dela. De acordo com o estudioso,

nas suas primeiras obras, as Prosas Bárbaras [...], Eça é um escritor do gênero a que depois se chamou "fantástico", e nas últimas, que săo vidas de santos, volta a esse caminho; as suas obras que foram chamadas "realistas" estăo entre aquele começo e este fim "fantásticos...". Săo um intervalo numa série vasta, tendo em conta que mesmo na fase "realista" da obra de Eça há vários romances que programaticamente nada têm de realistas, como 0 mandarim, A cidade e as serras, A ilustre casa de Ramires, e até onde falta qualquer propósito de coerência e de verosimilhança, como A relíquia. Sem falar de 0 mistério da Estrada de Sintra. (SARAIVA, 1995, p. 149-150).

Pode-se constatar que há um viés fantástico que está presente desde os primeiros até os últimos escritos de Eça de Queirós. O corpus desse estudo enquadra-se, portanto, dentro desses limites. Trataremos de analisar os folhetins "O milhafre", "O lume" e "Memórias duma forca", publicados no jornal Gazeta de Portugal em 1867, e, postumamente, compilados no volume Prosas Bárbaras (1903). 
Ana Teresa Peixinho (2002, p. 38-39), ao analisar as narrativas de Prosas Bárbaras, divide esses folhetins em três categorias: os que estariam no domínio do fantástico, no domínio do real ou no domínio programático. Para a pesquisadora, "O milhafre" e "O lume" ficariam no primeiro conjunto, enquanto que "Memórias duma forca" estaria inserido no segundo grupo, isto é, aqueles do domínio do real. Entretanto, para nós, essa narrativa também poderia estar enquadrada na primeira categoria, já que se observa, nesse texto, uma técnica semelhante à utilizada nos dois primeiros folhetins, pois, em "Memórias de uma forca", Eça utiliza a personificaçăo de um objeto inanimado ou de um ser irracional, figura de linguagem que também aparece em "O lume" e "O milhafre", fazendo com que se manifeste o efeito insólito. Além do mais, a hipótese que permeia esse estudo é que, nesses contos, haveria uma confluência entre o real e o fantástico, pois, apesar de serem observados elementos do fantástico nessas narrativas, também há a inserçăo de temas extraídos do contexto histórico-social daquela época, como a crítica à sociedade oitocentista, agravada pelo tom antiburguês desses folhetins.

Por outro lado, essa confluência entre o real e o fantástico também é apontada por Peixinho. Para a estudiosa, o contato de Eça com outros intelectuais da época, como Antero de Quental, fez com que ele compreendesse que "a literatura deverá ser entendida em estreita relaçáo com o processo histórico e todas as suas implicaçóes filosóficas e político-sociais deverâo ser por ela reflectidas" (PEIXINHO, 2002, p. 43). A pesquisadora também destaca que,

em Prosas Bárbaras, a par de discursos filosóficos proferidos por um milhafre, de deuses pagáos exilados, de diabos ambíguos e grotescos, de poetas satânicos e desesperados, de amantes perpetuamente insatisfeitos, existem operários explorados, lenhadores esfomeados, burguesas fúteis e capitais degradadas. Por outras palavras, o Romantismo de índole marcadamente satânica que explora a ambiguidade e morbidez nos folhetins mais fantásticos, coexiste com uma tendência, năo isenta de ironia, para retratar personagens, espaços e contextos extraídos do real. (PEIXINHO, 2002, p. 44).

Percebe-se, nos textos iniciais de Eça, que os elementos do fantástico coexistem com o contexto social. Assim, nos três folhetins que delimitam o corpus desse estudo, Eça dá voz ora a um animal (ao milhafre), ora a um elemento da natureza (o fogo/ lume) e ora a um objeto (a forca), fato este que evidencia o insólito nas narrativas, para fazer uma crítica ao homem oitocentista. Dessa forma, sâo válidas as ponderaçóes de Antonio Augusto Nery sobre os textos fantásticos de Prosas Bárbaras. O estudioso aponta que "neles já pairam as preocupaçôes de Eça com as desigualdades sociais e com as críticas voltadas a diversos aspectos da sociedade, temas que o acompanharam até sua produçăo derradeira" (NERY, 2010, p. 138). Com essa afirmaçăo, reforça-se a nossa hipótese de que Eça, ao fazer uso do fantástico, aponta a crítica social.

Antes de prosseguir com a análise dos contos, fazem-se necessárias algumas palavras para discorrer sobre o fantástico. Embora năo seja objetivo de nosso trabalho problematizar o conceito de fantástico, sabemos que esse termo é muito debatido pelos teóricos, ora prevalecendo um olhar bastante delimitado, como o de Todorov, ora uma visăo mais ampla, compreendendo-o sob uma perspectiva latu sensu. Muitos estudiosos, entretanto, utilizam o termo insólito para se referirem a textos nos quais săo observados acontecimentos inusuais, isto é, pouco prováveis de acontecer, tal como os pressupostos defendidos por Flavio García. Para ele, 
se o insólito năo decorre normalmente da ordem regular das coisas, senáo que é aquilo que năo é característico ou próprio de acontecer, bem como náo é peculiar nem presumível nem provável, pode ser equiparado ao sobrenatural e ao extraordinário, ou seja, àquilo que foge do usual ou do previsto, que é fora do comum, năo é regular, é raro, excepcional, estranho, esquisito, inacreditável, inabitual, inusual, imprevisto, maravilhoso. (GARCÍA, 2007, p. 20).

Utilizaremos, portanto, esse termo para fazer referência ao nosso corpus. Com essa sistematizaçăo, o fantástico estaria compreendido nesse conceito mais amplo, do insólito, já que dar voz a animais irracionais e objetos inanimados é algo fora do comum, estranho, inabitual, inusual, etc. A inserçáo do elemento fantástico/insólito, nesses três textos, se dá pelo elemento comum da personificaçăo/humanizaçăo de animais, elementos da natureza e objetos.

Por outro lado, "O milhafre", "Olume" e "Memórias duma forca" estăo próximos de uma leitura alegórica, evidenciando a complexidade e a dificuldade da categorizaçáo desses folhetins. Para Tzvetan Todorov, a alegoria ${ }^{3}$ invalidaria o fantástico. Segundo o teórico, "se o que lemos descreve um acontecimento sobrenatural, e que exige no entanto que as palavras sejam tomadas náo no sentido literal mas em outro sentido que năo remeta a nada de sobrenatural, năo há mais lugar para o fantástico" (TODOROV, 1975, p. 71). Entretanto, Maria Cristina Batalha, ao discorrer sobre o fantástico, reconhece a complexidade desse gênero literário e a flutuaçăo teórica desse termo, e admite que seria prudente "consideramos o conceito em seu plural - 'fantásticos'. À pluralidade de fantásticos associam-se adjetivos diversos que lhe completam o sentido e dăo formas mais perceptíveis ao gênero: grotesco, macabro, gótico, alegórico, metafísico, fantástico mágico, fantástico surreal etc." (BATALHA, 2011, p. 18, grifo nosso). A estudiosa reconhece, portanto, que a leitura alegórica também poderia estar situada dentro dos limites do fantástico. Assim, mesmo que para Todorov a alegoria anule o fantástico, para nós essas duas leituras (o texto lido sob o viés fantástico ou sob o viés alegórico) abarcariam as instâncias do insólito, pois nelas há o inusual.

$\mathrm{O}$ narrador queirosiano introduz o conto "O milhafre" afirmando que ele se trata de uma fábula: "seja-me permitida uma pequenina fábula"4 (QUEIRÓS, 2009, p. 71). Se utilizássemos os preceitos de Todorov, esse conto náo poderia ser enquadrado nos limites do fantástico, e sim no campo do alegórico, pois, para esse teórico, "a fábula é o gênero que mais se aproxima da alegoria pura" (1975, p. 71). Por sua vez, para Peixinho, esse conto representaria uma alegoria "do debate Espírito/Matéria - simbolizado pelo confronto entre Cristo/Homem" (2002, p. 50). Entretanto, devemos reconhecer que, desde o início do conto, há elementos insólitos, a começar pela figura de um santo de pedra que lê a Bíblia. O narrador relata que, "a essas horas, uma criança, tăo pobre e tăo esfarrapada como o antigo

3 De acordo com Todorov, "a alegoria implica na existência de pelo menos dois sentidos para as mesmas palavras; diz-se às vezes que o sentido primeiro deve desaparecer, outras vezes que os dois devem estar presentes juntos. Em segundo lugar, este duplo-sentido é indicado na obra de maneira explícita: nâo depende da interpretaçâo (arbitrária ou náo) de um leitor qualquer". (1975, p. 71, grifo do autor).

4 Utilizamos, como referência, a Ediçâo Crítica das Obras de Eça de Queirós, coordenada por Carlos Reis. Os contos "O milhafre" e "Memórias duma forca" encontram-se no volume Contos I (2009), editado por Marie-Hélène Piwnik. 
pastor S. Joăo, vinha deitar-se junto do nicho do santo. E entăo, o santo afastava um pouco o livro, e toda a noite ficava cobrindo com a grande luz dos seus olhos aquela criança miserável, adormecida sobre as lajes" (QUEIRÓS, 2009, p. 72). A presença de uma estátua que se move mostra o caráter insólito da narrativa.

Nota-se já a inserçăo de elementos religiosos relacionados ao insólito. Além disso, nesse trecho percebe-se a simpatia do narrador para com os pobres, posiçáo essa que será semelhante ao olhar de Eça para as camadas mais baixas, tal como indicam os apontamentos de Saraiva, cuja abordagem define o Eça das Prosas Bárbaras como um antiburguês, ao afirmar que o autor teria herdado "o preconceito romântico e todo literário contra o burguês" (SARAIVA, 1982, p. 80). Ainda segundo o especialista português, "o burguês é símbolo da materialidade dos tempos, da civilizaçăo exclusivamente mercantil e industriosa que se desenvolve em face do sonho e da boémia dos homens de letras e artistas" (SARAIVA, 1982, p. 80). O crítico exemplifica a simpatia de Eça pelas camadas populares com uma passagem de "Memórias duma forca", na qual esse pedaço de madeira enforca um pobre operário, que "no Inverno náo teve trabalho, nem lume, nem páo. Tomado dum desespero nervoso, roubou. Foi enforcado ao sol-posto" (QUEIRÓS, 2009, p. 114).

Retomando a "O milhafre", verificam-se outros elementos que evidenciam o insólito na narrativa, como a casa arruinada, a sala enorme e escura, que apontam para uma possível ambientaçâo de mistério. Além do mais, nesse cômodo há um grande crucifixo de madeira, cuja descriçáo remete ao insólito:

\begin{abstract}
Sobre a cabeça macerada do Cristo, as traves podres do tecto abriam uma larga fenda. Por ali vinha a chuva escorrer-lhe nos cabelos como o antigo suor das Oliveiras, vinham os granizos magoá-lo como as pedras da Paixăo, vinha o sol alumiá-lo como a tocha de Judas, e a lua vinha, também, torná-lo mais lívido, como naquela noite em que Ele depois de ter visto a gente soluçante descer para Jerusalém, sentiu pousar na sua cruz um rouxinol que toda a noite cantou.
\end{abstract}

Sobre a cabeça e sobre os braços de Cristo havia teias de aranha; em baixo os ratos roíam-lhe a cruz.

Entăo o homem sentiu que aquele seio constelado, e aquela boca donde saiu a revelaçăo do amor, do perdăo, e da alma, tinham o pó, a podridáo, a caliça e os bichos; e que, se um dia Cristo vendo o homem aflito e miserável lhe tinha arrancado da alma o mal, náo era muito que o homem, encontrando Cristo abandonado, profanado e roído, lhe limpasse da cabeça as aranhas! (QUEIRÓs, 2009, p. 73-74).

Entretanto, tal descriçăo năo se limita a uma imagem insólita de um Cristo roído pelos ratos. De acordo com Saraiva, esse Cristo seria um símbolo do desprezo moderno e burguês pelo espírito e pelo ideal. O pesquisador destaca que

Há aqui uma sobrevivência romântica. Garrett censurava a sociedade dos “baróes" e dos "agiotas", que plantava batatas e construía caminhos de ferro, por deixar ao abandono as velhas ruínas góticas; e é precisamente por ser algo que se opóe ao industrialismo moderno e ao espírito estreitamente prático de que acusa os seus conterrâneos que Garrett valoriza aquelas ruínas - símbolo de algo que năo é prático nem útil, que é um puro valor subjectivo, que é, em suma, para empregar a terminologia romântica, "puro ideal". É esta depreciaçăo do burguês, do materialista, a que Eça julga personificada na pessoa de Cristo, portador de uma mensagem que, segundo pensava, nada tinha 
de material, era alheia a qualquer ideia de progresso técnico, estava toda na "alma", era puramente "ideal". E a imagem de Cristo roída pelos ratos exprime o desinteresse "burguês" por este "ideal". (SARAIVA, 1982, p. 85).

Verifica-se, segundo os pressupostos defendidos pelo especialista português, uma possível leitura alegórica dessa narrativa, na qual a imagem de Cristo abandonado, com teias de aranha e roído pelos ratos, significaria o interesse materialista do burguês e seu desprezo pelo espírito. Para Nery, o Cristo roído serviria para exprimir "o desinteresse do burguês pelos ensinamentos de Jesus, os quais soam como contraposiçấo à sociedade finissecular do Oitocentos que desprezou a espiritualidade e o ideal, preferindo a modernidade, a técnica e o lucro" (2010, p. 136).

A inserçâo de um outro elemento insólito reforça o posicionamento destacado por Saraiva e por Nery. Trata-se de um milhafre que interrompe a açâo de um homem, que pretendia limpar a estátua de Cristo: "com a antiga voz dos animais da Bíblia, do Apocalipse e dos livros dos profetas disse surdamente: 'Homem, deixa a cruz sossegada!"' (QUEIRÓS, 2009, p. 74). Esse homem, de acordo com Nery, "sugere representar a humanidade, especialmente a classe burguesa" (2010, p. 136). O pássaro começa a criticar o homem oitocentista, em relaçăo ao campo material, espiritual e do pensamento:

As cidades săo limpas e caiadas, só as consciências é que têm nódoas; as praças estăo cheias de iluminaçôes, só os coraçôes é que estâo escuros; os cais estấo arejados, só os espíritos é que sufocam; os corpos estăo săos, cobertos de estofos, frescos e resplandecentes, só as almas é que andam nuas, miseráveis e leprosas. De resto tendes o riso, a farsa, os paraísos artificiais, as arcas venais, e também o esfriamento do túmulo! Oh amigos íntimos dos vermes, como vós cuidais do corpo, e o lavais, e o amaciais, e o engordais - para a pastagem escura das covas! (QUEIRÓS, 2009, p. 75).

Nessa crítica, o milhafre aponta uma dicotomia. De um lado, a ave mostra que o progresso técnico trouxe benefícios ao homem (como o desenvolvimento das cidades); por outro lado, nesse processo, a humanidade se tornou materialista, esquecendo-se de sua espiritualidade. Assim, concordamos com Peixinho, cujas reflexóes mostram que "a concepçăo de progresso [em Prosas Bárbaras] era pessimista e disfórica, já que progresso era um factor deformador e corrosivo do homem e do ambiente, opondo-se à luz, à simplicidade e à originalidade da Natureza năo corrompida" (PEIXINHO, 2002, p. 47).

Também podem nos ser úteis as explanaçôes de Orlando Grossegesse, que analisa a crônica "A Inglaterra e a França julgadas por um inglês", outro texto de Eça de Queirós no qual se observa a personificaçăo, um processo semelhante ao de nosso corpus, pois, nessa narrativa, um căo analisa criticamente a sua época. Segundo o pesquisador, haveria três motivos que explicariam o procedimento do uso de animais com capacidades humanas. Para Grossegesse,

em primeiro lugar, na transposiçáo de condiçōes sociais para o nível animal é possível revelar melhor os defeitos humanos. Em segundo lugar, o disfarce animal facilita uma enunciaçăo que escapa às pressóes da ordem do discurso (Foucault, 1971) vigente numa determinada sociedade. Isso porque a um animal normalmente năo se atribui juízo e muito menos língua inteligível, capacidades civilizadoras reclamadas em exclusivo pelo homem. $O$ facto de se fazer falar um animal pode pôr em dúvida esta óbvia superioridade humana. Questionar a civilizaçăo é, portanto, o terceiro motivo para a invençăo de um animal filosófico. (1991, p. 131, grifos do autor). 
Acreditamos que as reflexóes do professor săo pertinentes para a análise dessa produçâo inicial do autor de Os Maias, pois percebemos que o animal (o milhafre) serve como um instrumento que revela os defeitos humanos - como em "O milhafre", a ave critica negativamente o homem por ele ter se afastado do mundo espiritual e se convertido ao mundo materialista. Veremos, a seguir, uma crítica semelhante também presente nas outras duas narrativas. Dessa forma, como uma tentativa de alargar a abordagem de Grossegesse, elencamos que tais ponderaçôes sâo condizentes também para elementos da natureza e objetos (o lume e a forca), pois ambos criticam o homem oitocentista. Ademais, no que diz respeito ao segundo e ao terceiro motivos, nota-se que o discurso do milhafre, do lume e da forca apresentam um certo posicionamento semelhante ao de Eça-autor, como já mencionado pelas reflexōes de Saraiva, isto é, aponta-se para uma visăo antiburguesa do mundo.

Apesar de Grossegesse destacar que o discurso do animal "escaparia às pressôes" da sociedade, verifica-se que tal recurso, nessas narrativas, săo críticas disfarçadas, isto é, o discurso do animal e dos objetos poderia ser proferido por homens do século XIX (Eça de Queirós, por exemplo), como uma forma de questionar a civilizaçāo. Assim, de acordo com Peixinho, o parágrafo que antecede ${ }^{5}$ “O milhafre" mostra,

por um lado, a angustiante noçâo de inutilidade e impotência do jovem Autor, perante a ruína do seu país; por outro lado, julgamos poder encará-la como sintoma prematuro de um certo decadentismo e de um certo vencidismo derrotista que virá a contaminar Eça e os seus companheiros de geraçáo, anos mais tarde. [...] Apesar de tudo, interessa-nos realçar, nestas palavras, o papel de observador assumido por Eça que assiste, de forma distanciada, ao desenrolar de acontecimentos do seu país. (PEIXINHO, 2002, p. 45-46).

Vemos, portanto, na nota introdutória, uma visăo bem parecida com a crítica posta pelo milhafre, isto é, evidencia-se o progresso técnico da modernidade europeia, através de um tom jocoso, no qual parecem ser sobrepostas qualidades negativas desse desenvolvimento. Além disso, é apontada a situaçăo da literatura entre as "agonias de pensamento" em Portugal. Ironicamente, o poeta lírico chega a ser comparado a uma profissâo de perigo, devido à sua marginalidade, uma vez que se infere que tal

5 De acordo com uma nota de rodapé de Marie Hélène Piwnick (2009, p. 71), essa introduçáo foi publicada na Gazeta de Portugal, contudo, ao ser compilada no volume Prosas Bárbaras, a depender da ediçáo e da organizaçăo, tal introduçăo foi suprimida. Assim, transcrevemos a nota introdutória disponível na Ediçāo Crítica, para que o leitor possa ter acesso: "Meus amigos. A literatura em Portugal está a agonizar; morre burguesmente e insipidamente: nem ao menos tem os efeitos de luz extravagantes de todos os acasos celestes.

É uma doidice o querer passar, criar, criticar, nesta terra onde nascem as laranjeiras, como diz a cantiga de Mignon. Se ainda houvessem cabelos seria muito preferível ser fabricante de caixinhas de banha.

Seria mesmo talvez melhor a profissăo de poeta lírico, se năo fosse uma profissăo perigosa. Ainda há pouco, um pediu em casamento náo sei que doce açucena, moradora na Baixa; o pai dela interrompeu a história dos idílios sacrossantos e municipais para perguntar ao namorado gentil, qual era a sua profissăo. - Sou poeta lírico, respondeu ele, e vivo do meu estado. - O velho ergueu-se de golpe, tomou uma bengala e espancou o poeta lírico, laureado em três cançonetas exóticas.

Todavia, é com verdadeira alegria que me acho neste canto que a política me deixa. Faço deste canto, de boa vontade o lugar de espetáculo para assistir às últimas agonias do pensamento em Portugal. Trata-se de cair bem, meus amigos, como os antigos gladiadores: oh egoísmo humano, os que vâo morrer saúdam-te!

E depois, meus caros amigos, eu acho admirável a sociedade moderna, a sua política perfeita, a sua indústria magnífica, a sua agiotagem providencial, o seu luxo simpático, a sua retórica florida, a sua arte económica, os seus sonhos de oiro, mas persisto em invejar aqueles que como o antigo Daniel podem contemplar as estrelas, enquanto os bichos sociais se devoram na sombra." (QUEIRÓS, 2009, p. 71). 
profissional năo teria espaço na sociedade burguesa oitocentista. Assim, tal nota pode ser lida como uma prenunciaçấo para as palavras proferidas pela ave, pois há uma continuidade entre a crítica denunciada pelas duas entidades, evidenciada pela condenaçâo do materialismo burguês.

Passando ao segundo texto, verifica-se que, em "O lume", o elemento insólito é inserido de forma semelhante a "O milhafre", isto é, o lume recebe voz frente a uma figura humana. Atenta-se também que, antes desse acontecimento, a natureza é retratada de forma humanizada. Saraiva aponta que, nos textos que compóem as Prosas Bárbaras, é possível notar uma visăo antropomórfica da natureza. O estudioso destaca que, de acordo com essa concepçâo, isso conduziria "a uma visăo mitológica e vagamente politeísta da natureza - cada árvore ou cada rochedo tem a sua alma" (SARAIVA, 1982, p. 75), como pode ser observado, por exemplo, nessa passagem: "As árvores erguem os braços nus, miseráveis e suplicantes. E as águas [...] têm agora vozes vingativas e más. O vento é rouco e lento como um canto católico de ofícios"6 (QUEIRÓS, 2004, p. 149), fazendo com que aumente os traços insólitos presentes nesse conto. Além disso, se no texto anterior constatou-se que o progresso técnico é visto de forma negativa, observa-se que, em "O lume”, isso se dá de forma semelhante. Antes do discurso do fogo, aponta-se sobre um homem moderno que vive de forma infeliz:

entăo, o homem sente a sua pequenina e inútil alma afundar-se no tédio, silenciosamente, como um navio roto - numa calmaria, e vai por instinto dar-se à intimidade consoladora da lareira, das brasas e do fogo. E enquanto a força vital se dissolve numa sonolência fluida, ele sente aos seus pés, uma pequena voz, alegre, inquieta, clara, que lhe fala como num êxtase profano. (QUEIRÓS, 2004, p. 149).

Apesar de o narrador destacar o "êxtase profano" dessa manifestaçăo insólita, algo, portanto, que deveria estar distante da religiosidade, o que se vê no discurso do lume é justamente o oposto, pois o fogo também recebe contornos religiosos, tal como a ave de "O milhafre", já que essa personificaçăo é tida como o próprio Deus, isto é, um ser superior e sábio: "Sou eu, diz a voz, eu o teu velho camarada, o bom lume. Sou eu, o teu velho Deus misterioso. Eu que te quero bem, e que te dei o que há em ti de grande e de justo - a família e o trabalho" (QUEIRÓS, 2004, p. 149).

Ao narrar a história da humanidade, vista sob a perspectiva do lume, é ressaltado que ele esteve presente desde as civilizaçôes mais antigas, reforçando sua característica onipresente. Deste modo, apesar de o fogo estar conversando com um homem moderno, ele náo fala especificamente desse sujeito, mas da humanidade em geral, pois esse elemento natural esteve presente desde os tempos mais remotos: "A minha história é triste, e luminosa, e terrível, e imunda e meiga. Eu fui o teu companheiro das noites da Índia, o consolador e o purificador; eu fui o Moloch das religiōes da velha África, ensanguentado e trágico: e sou agora o escravo a quem tu mandas mover as máquinas" (QUEIRÓS, 2004, p. 149). Nota-se, portanto, o caráter reflexivo do lume, ao reconhecer, em um tom de lamento, que ele fez parte da barbárie humana (sacrifícios humanos nas fogueiras), apontando também a crítica à sociedade industrial.

6 Utilizamos, como referência, a Ediçâo Crítica das Obras de Eça de Queirós, coordenada por Carlos Reis. A narrativa "O lume" encontra-se no volume Textos de Imprensa I (da Gazeta de Portugal) (2004), editado por Carlos Reis e Ana Teresa Peixinho. 
Além disso, o discurso dele é carregado de valores que remetem a uma vida simples e primitiva: "Na Índia, lembras-te? durante noites primitivas, eu fui o bom Agnì que te ilumiava, que espantava os chacais e as onças, e protegia, como um templo, os teus amores religiosos e simples" (QUEIRÓS, 2004, p.150). Por outro lado, o afastamento desse estágio é condenado pelo lume:

Quando saías de ao pé de mim, da tua cabana ajoelhada ao sol, encontravas-te só, entre os seres implacáveis, o mar que te ladrava, a vegetaçăo espinhosa que te mordia, a chuva que te paralisava, a neve que te dava sudários. Tudo, sob a pressâo doentia do sol, era para ti força inimiga ou forma resplandecente do mal. (QUEIRÓS, 2004, p. 150).

Dessa forma, critica-se o progresso, uma vez que esse distanciamento do homem ao mundo natural ocasiona uma mudança na funçâo do fogo, pois ele passa a ser usado para praticar o mal: "Por ti tenho feito o mal. Fui eu que matei Giordano Bruno, e Joăo Huss, e tantos santos, e tantos mártires, e tantos alucinados de Deus! Fui eu que queimei nas cidades misteriosas de África as crianças e as virgens no altar de Moloch. Por ti, eu que sou a paz, fui devastaçáo" (QUEIRÓS, 2004, p. 151). É importante ressaltar que a principal crítica do lume é feita à sociedade moderna, à era das máquinas, ainda que ele discorra que matou homens queimados nos sacrifícios na África e na Inquisiçâo, portanto, náo seria uma crítica restrita ao século XIX.

Assim, o fogo relembra as mudanças transcorridas pelas revoluçóes sociais: "quiseste criar os Direitos do Homem, trouxeste um mal divino chamado Liberdade, que vai sempre fugindo de ti, só às vezes se volta de repente, para te borrifar de sangue! Quiseste ir construir a adoraçăo do corpo e da matéria exclusiva: trouxeste [...] o egoísmo brutal" (QUEIRÓS, 2004, p. 152). Aqui, Eça relaciona a Revoluçăo Francesa com o período do Terror e o advento do capitalismo. Além disso, o lume já demonstra que seria preciso estar inserido dentro dessa nova sociedade, com o crescimento do poder da burguesia: "Durante as revoluçôes e as lutas, andei errante, miserável, sobrecarregado de infâmias, e, para viver - vendendo-me ao carrasco" (QUEIRÓS, 2004, p. 153 - grifo nosso), evidenciando, assim, uma prática de exploraçăo do mundo capitalista. Por fim, narra-se a insatisfaçâo do fogo perante as mudanças provocadas pela Revoluçâo Industrial:

A mim que embalava as almas, fazes-me mover os aços. Embalo que era amor, movimento que é força: os dois termos da tua vida - pureza e putrefacçăo! Eu que vivia, alumiava, criava em liberdade estou encadeado e martirizado, na tarefa brutal das indústrias. Fazes-me o motor da tua miséria. Nas fábricas, as criaturas doentias, as crianças estioladas, as mulheres definhadas e soluçantes! Fazes-me mover a vapor estas misérias. Sou o colaborador dos teus martírios. Tu homem, tomas o fogo, o ser sagrado, por ajudante de execuçóes! Dás-me por salário a infâmia. Fazes de mim a explosâo. Obrigas-me a devastar na guerra. (QUEIRÓS, 2004, p. 153 - grifo do autor).

Portanto, as declaraçóes desse elemento da natureza também se enquadram numa perspectiva antiprogresso, pois há uma crítica à funçâo do fogo no mundo capitalista, apontando, entre outras coisas, o trabalho infantil e a insalubridade dos espaços industriais. De acordo com Saraiva, nesse conto, já estaria posto o bucolismo contemplativo, também presente em obras futuras, como n'A cidade e as serras: "o progresso técnico só o vê como uma coisa lamentável porque rouba o homem à doçura e fresquidăo dos 
campos [...] e, a acreditarmos o conto 'O lume', os homens deviam ter ficado ao redor do lume misterioso [...] na paz da vida primitiva" (SARAIVA, 1982, p. 80). Com base nas afirmaçôes de Saraiva, podemos estabelecer, dessa forma, uma crítica às mudanças provocadas pelo comportamento humano. Percebe-se, pelo uso do lume, que ele era usado para práticas de subsistência, por exemplo, privilegiando-se uma vida simples. Entretanto, tal objeto passa a ser usado contra a humanidade e contra a natureza, isto é, serve como uma arma de guerra e instrumento de trabalho na sociedade industrial. O homem deixa de usá-lo em seu estado primitivo (fogo), aprimora-o e, nesse progresso técnico, esse elemento denuncia as mazelas provocadas pelo desenvolvimento da sociedade, evidenciando, dessa forma, que tal progresso faz com que o homem perca suas qualidades positivas, isto é, aquelas que remetem ao bem, à paz e ao amor, tal como pode ser constatado na fala dele: "Eu que sou a pureza, o trabalho, a família, a paixăo casta, levas-me a ser o mal, a viuvez, o pranto e a dor! Tenho um cortejo de ambulâncias e de macas, eu que era o firmamento dos berços! Náo! Maldita seja a árvore que consentir em ser forca, e o fogo que consentir em ser explosáo!" (QUEIRÓS, 2004, p. 153-154).

Esse folhetim também representa um ponto de vista similar ao de "O milhafre", mostrando que o afastamento da espiritualidade e o desenvolvimento técnico săo prejudiciais à humanidade. Nesse conto, há uma valorização da vida simples que o homem supostamente teria em contato com a natureza. Em meio a ela, o fogo é descrito com características bem próximas a de um Deus bondoso. No entanto, o afastamento do homem ao meio natural traz consequências negativas. Além disso, é interessante notar a citaçăo, exposta no trecho acima, sobre uma árvore que aceitaria ser forca, assunto do próximo conto a ser analisado. Como veremos, o pedaço de madeira de "Memórias duma forca" também condena esse ato, criticando, dessa forma, as açóes humanas.

O terceiro texto que compóe o nosso corpus inicia-se com um recurso bastante comum do romantismo ${ }^{7}$ : trata-se da tópica do suposto manuscrito encontrado. Logo no início, o narrador destaca sobre o tom de mistério da origem desse material: "Foi por um modo sobrenatural que eu tive conhecimento deste papel, onde uma pobre forca apodrecida e negra, dizia alguma coisa da sua história. Esta forca intentava escrever as suas trágicas Memórias" (QUEIRÓS, 2009, p. 107). Nota-se, portanto, a origem supostamente sobrenatural e insólita do manuscrito. Ademais, esse narrador filtraria as memórias da forca, já que ele afirma que,

Entre os apontamentos que deixou, os menos completos sâo estes que copio resumo das suas dores, vaga aparência de gritos instintivos. Pudesse ela ter escrito a sua vida complexa cheia de sangue e de melancolia! É tempo de sabermos enfim qual é a opiniấo que a vasta natureza, montes, árvores e águas, fazem do homem imperceptível. Talvez este sentimento me leve ainda algum dia a publicar papéis que guardo avaramente e que săo as Memórias dum átomo, e os Apontamentos de Viagem duma raiz de Cipreste. (QUEIRÓS, 2009, p. 107).

7 Grossegesse aponta que "o discurso editorial apenas alude ao tema romântico de ocultar a escrita, um tema que ainda está bem presente nos escritos juvenis de Eça de Queiroz: nas Prosas Bárbaras (1866/1867) aparece abundantemente o discurso editorial que introduz, náo só as declaraçôes filosóficas de um milhafre, mas também a autobiografia de uma forca, e discute-se, em manuscritos encontrados, 0 percurso biográfico do poeta romântico." (GROSSEGESSE, 1991, p. 143). 
Grossegesse, ao comentar o recurso do manuscrito encontrado e seu uso com um animal filosófico, destaca que tal método "năo serve para confirmar a autenticidade do documento ficticiamente apresentado por um editor: é inverosível demais que um animal fale ou escreva. Pelo contrário, essa inverosimilhança óbvia torna o princípio de veracidade ridículo [...]" (GROSSEGESSE, 1991, p. 135). Embora em "Memórias duma forca" năo se trate de um animal filosófico, mas sim de um objeto, acreditamos que tais reflexóes também podem ser pertinentes à forca. Assim, mesmo que o leitor saiba sobre a inverossimilidade do conteúdo das memórias desse pedaço de madeira, Eça o trata de modo verossímil, pois a vida da forca é narrada de modo humanizado:

Sou duma antiga família de carvalhos, raça austera e forte - que já na Antiguidade deixava cair dos seus ramos - pensamentos de Platăo. Era uma família hospitaleira e histórica: dela tinham saído navios para a derrota tenebrosa das Índias, contos de lança para os alucinados das Cruzadas, e vigas para os tectos simples e profundos que abrigaram Savonarola, Spinoza e Lutero. (QUEIRÓS, 2009, p. 108).

Dessa forma, percebe-se que a futura forca também participa da História ocidental, mostrando, deste modo, a linhagem nobre desse pedaço de árvore. A humanizaçáo é reforçada no modo de agir desse elemento. Segundo Simōes, essa árvore "tem hábitos de pessoa social" (1945, p. 168), e parece já estar integrada a um modo de vida capitalista: "Meu pai esquecido das altas tradiçôes sonoras e da sua heráldica vegetal teve uma vida inerte, material e profana [...] Era uma árvore materialista" (QUEIRÓS, 2009, p. 108). Além disso, a forca aponta para outras características da burguesia, como a marginalidade dos artistas, também presente na nota introdutória de "O milhafre", citada por nós anteriormente, em nota de rodapé:

Um dos meus irmáos foi levado para ser tablado dos palhaços: ramo contemplativo e romântico ia todas as noites ser pisado pela chufa, pelo escárnio, pela farsa e pela fome! O outro ramo cheio de vida, de sol, de poeira, áspero solitário da vida, lutador dos ventos e das neves, forte e trabalhador, foi arrancado dentre nós, para ir ser tábua de esquife! - Eu o mais lastimável, vim a ser forca! (QUEIRÓS, 2009, p. 108).

Ao discorrer sobre o destino de um de seus irmáos, o pedaço de madeira destaca o espaço marginal presente no meio artístico. Peixinho destaca que Eça está preocupado por tipos sociais marginalizados pela sociedade materialista. A estudiosa reflete que "mais clara parece-nos ser a inclinaçăo por todos aqueles que se caracterizam por uma relativa independência, por uma vida livre e sem preconceitos e, sobretudo, pela capacidade inventiva: o saltimbanco é disso um claro exemplo" (PEIXINHO, 2002, p. 52). Embora nesse conto nâo se tenha uma referência ao saltimbanco - profissăo destacada pela estudiosa - verifica-se que o espaço do circo é condizente com as explanaçôes da pesquisadora, pois, de acordo com as memórias da forca, tal espaço é propício para a pobreza e, portanto, para a desigualdade social. Dessa forma, relembramos a afirmaçâo de Saraiva, posta no início de nosso trabalho, sobre o olhar simpático de Eça para com os marginalizados, no qual o crítico exemplifica sua explanaçăo com um trecho desse conto, no qual a forca lamenta ter matado um operário que roubou por năo ter trabalho, nem comida, mostrando, com isso, a preocupaçâo de Eça com assuntos de teor social em textos fantásticos.

Percebe-se a infelicidade do pedaço de madeira com o seu próprio destino, já que ele lastima ter virado forca (ponto de vista semelhante ao do lume, no conto anterior). 
É pertinente mencionar que esse folhetim, publicado no final de 1867 (22 de dezembro), dialoga fortemente com o contexto daquele tempo, pois esse é o ano da aboliçáo da pena de morte em Portugal. Ana Paula Fernandes Rodrigues, ao comentar sobre a estadia de Eça de Queirós em Évora, período em que ele escreveu para o jornal “Distrito de Évora", discorre que, em 1867, assistiu-se a um "período de relativa acalmia política e a uma série de reformas sociais, entre a quais se destacam a aboliçăo da pena de morte, com a reforma do sistema penal e prisional [...]" (RODRIGUES, 2008, p. 10).

É provável, portanto, que Eça, ao escrever "Memórias duma forca", estivesse fazendo uma denúncia da violência humana característica da pena de morte, e manifestando apoio ao projeto político que propunha a sua aboliçăo. Ademais, a interferência do homem na natureza é vista de modo negativo: “Um dia, um daqueles homens metálicos que fazem o tráfico da vegetaçâo veio arrancar-me à árvore" (QUEIRÓS, 2009, p. 109). Logo, novamente, nesse texto, há uma crítica ao desenvolvimento técnico: "comecei entăo a compreender que uma grande imundície cobre a alma do homem" (QUEIRÓS, 2009, p. 110). Assim como nos dois outros contos, o homem parece perder as suas qualidades com o progresso. Nesse folhetim é nítido o contraste que há entre o meio natural e o meio urbano: "As árvores depois de terem sido colocadas por Deus na floresta com os braços estendidos - para abençoar a terra e a água - fossem arrastadas para as cidades, e obrigadas pelo homem a estender o braço da forca para abençoar os carrascos!" (QUEIRÓS, 2009, p. 113), reforçando, portanto, os aspectos negativos da modernidade e do progresso.

Acreditamos, dessa forma, que os apontamentos de Saraiva sobre a natureza em Prosas Bárbaras sejam pertinentes para compreendermos a relaçăo do homem com o meio natural. O pesquisador português destaca que, nessa coletânea, "o homem é um breve e fugidio afloramento da natureza" (SARAIVA, 1982, p. 77). Percebe-se que, quanto mais o homem se afasta dela, mais ele fica propício a desenvolver qualidades negativas. Assim, pela leitura desses contos, entende-se que o progresso ocasionou o afastamento do homem do meio natural e, consequentemente, fez com que ele adquirisse características negativas e nâo pudesse mais ter uma vida simples e feliz. Além disso, com esse progresso, infere-se, sobretudo em "O milhafre" e em "O lume", que o homem perdeu também a sua religiosidade e se rendeu ao materialismo da sociedade do século XIX.

Pode ser vista, portanto, uma crítica ao homem oitocentista (e consequentemente ao progresso desencadeado por suas açóes) nas três narrativas abordadas nesse estudo. Percebe-se, além disso, a complexidade da prosa inicial de Eça de Queirós. Apesar de ser visível a incursâo pelo fantástico/insólito, nota-se nesses escritos temas extraídos do contexto histórico. Assim, é possível constatar nos textos de Prosas Bárbaras a preocupaçâo de Eça com assuntos de teor social. A complexidade é aumentada devido à diversidade na forma com que Eça trata o fantástico, uma vez que há uma oscilaçâo na definiçăo dessa produçăo inicial.

Embora críticos reconheçam a presença do fantástico nessa obra, há uma dificuldade em caracterizar tais escritos. Peixinho, por exemplo, situa "Memórias de uma forca" nos textos que estariam no domínio do real. Entretanto, há, nesse conto, situaçôes insólitas - uma forca que escreve as suas memórias -, distanciando-se, dessa forma, da definição proposta pela pesquisadora portuguesa. 
Todavia, concordamos que há uma fronteira entre o real e o fantástico bastante tênue nos folhetins publicados por Eça de Queirós. Além disso, ao tratar de três textos cujo elemento comum é a personificaçăo de um animal/objeto/elemento da natureza, notamos que essas narrativas também estariam bem próximas de uma leitura alegórica, de acordo com alguns estudiosos.

Por sua vez, Batalha admite que a leitura alegórica estaria compreendida nos contornos do fantástico. Contudo, por uma questăo de sistematizaçăo, reconhecemos a complexidade do fantástico, e propomos uma abordagem que abarcaria a leitura fantástica e a alegórica: esses três contos, portanto, poderiam ser lidos sob o viés do insólito, pois ainda que nos referíssemos ao fantástico ou ao alegórico estaríamos no campo desse conceito. Admitimos, dessa forma, que as três narrativas apresentam em comum um elemento insólito, trazido à tona por meio da humanizaçấo do animal, do elemento da natureza ou do objeto. Assim, a personificaçáo do milhafre, do lume e da forca seriam representaçóes insólitas para tratar de assuntos inseridos no campo do real, fazendo uma crítica ao homem oitocentista.

\section{REFERÊNCIAS}

BATALHA, M. C. Introduçâo. In: (Org.). O fantástico brasileiro: contos esquecidos. Rio de Janeiro: Caetés, 2011.

GARCÍA, F. O "insólito" na narrativa ficcional: a questăo e os conceitos na teoria dos gêneros literários. In: (Org.). A banalizaçāo do insólito: questōes de gênero literário - mecanismos de construçăo narrativa. Rio de Janeiro: Dialogarts, 2007, p.11-22.

GROSSEGESSE, O. O animal filosófico e a escrita autobiográfica. De E. T. A. Hoffmann a Eça de Queiroz. Runa. Revista portuguesa de Estudos Germanísticos, n. 15-16, Coimbra, p. 131-149, 1991.

NERY, A. A. Diabos (diálogos) intermitentes: individualismo e crítica à instituiçăo religiosa em obras de Eça de Queirós. 2010, 259 f. Tese (Doutorado em Literatura Portuguesa) Doutorado em Letras: Faculdade de Filosofia, Letras e Ciências Humanas, Universidade de São Paulo, São Paulo, 2010.

PEIXINHO, A. T. A gênese da personagem queirosiana em "Prosas Bárbaras". Coimbra: Minerva, 2002.

QUEIRÓS, E. de. Textos de Imprensa I (da Gazeta de Portugal). Lisboa: Imprensa NacionalCasa da Moeda, 2004.

. Contos I. Lisboa: Imprensa Nacional-Casa da Moeda, 2009.

REIS, J. B. Introduçâo: Na primeira fase da vida literária de Eça de Queirós. In: QUEIRÓS, E. de. Prosas Bárbaras. Porto: Lello \& Irmăo, 1951, p. 5-53. 
RODRIGUES, A. P. F. Eça de Queirós e as páginas esquecidas do Distrito de Évora. 2008, 147f. Dissertaçâo (Mestrado em Literatura e Cultura Portuguesas) - Mestrado em Literatura e Cultura Portuguesa: Universidade Aberta, Lisboa, 2008. Acesso em: 19 mar. 2018. Disponível em: 〈http://hdl.handle.net/10400.2/611〉.

SARAIVA, A. J. As ideias de Eça de Queirós. Lisboa: Bertrand, 1982.

O manto da fantasia. In: . A tertúlia ocidental: estudos sobre Antero de Quental, Oliveira Martins, Eça de Queirós e outros. 2. ed. Lisboa: Gradiva, 1995. p. 149-157.

SIMŌES, J. G. Eça de Queiroz: o homem e o artista. Lisboa: Dois Mundos, 1945.

TODOROV, T. Introdução à literatura fantástica. Săo Paulo: Perspectiva, 1975.

Submetido em 21 de março de 2018 Aceito em 08 de junho de 2018 